the baker, the dressmaker, the draper, the landlord, the tailor, and other tradesmen. The objects of the Act would have been more fully accomplished had it empowered local authorities to grant a moderate fee to any licensed practitioner who attended a case of confinement in circumstances precluding any hope of any other re. compense. The present Government seems inclined to pass enactments to ameliorate the condition of the masses, and if any of its measures would make it impossible for anyone to spend in drinking, betting, and smoking the money that should be spent in supplying himself or herself and dependents with the necessaries of life the above Act and many others would never have been required. Until restrictions are put on these three bad habits, so that no one could spend more than a certain amount on either of them-the amount allowed to be limited to income and obligationsall other ameliorative measures will be comparatively useless. Slavery has been abolished in the British dominions, but there are still a great many people who would be better to be still in slavery under a kind master. They are quite unworthy of their freedom and cannot enjny it properly, and if the present Government passes rest $j$ cti e measures to prevent these unworthy people from injuring them-elces, $1 \mathrm{~h}$ ir dependents, or the community generally, then others who need no such restrictions should cheerfully acquiesce in the new arrangements for the sake of their we iker brethren. It is hoped and expected that Parliament, so on to as emble, will put restrictions on these three great evils.

I am, Sir, yours faithfully,

PS.-It is certainly an outrage on humanity and a disgrace to civilisation that a poor woman in labour cannot command skilful attention in her dire distress.

\section{THE MEDICAL INSPECTION OF SCHOOL CHILDREN.}

To the Editor of THW LANCET.

SIR, - I should be much obliged if your readers in other parts of the country would favour the medical profession with information as to how their county councils are going to carry ont the medical inspection of school children. Are they going to appoint whole-time medical inspectors specially for this purpose or are they going to intrust the work to be done to general practitioners? It appears to me that the claims of the latter are being overlooked in the matter and that the county councils, in appointing a special staff wholly for this work, are embarking on an expensive method. The inspection is one which, in my opinion, will require great tact, and in this the knowledge of the local practitioner would be invaluable.

Dec. 28th, 1907

I am, Sir, yours faithfully,

General Practitioner.

\section{A PERSONAL EXPLANATION.}

\section{To the Editor of THE LANCET.}

SIR, - Will you permit an old correspondent whose first contribution appeared in your pages more than 50 years ago to make a personal explanation? A few weeks ago, in sorting some papers that had accumulated, I came across a circular or report from the Antivaccination Society. Glancing over it I saw a list of correspondents of the society in foreign parts. To my extreme disgust I found my own name published as the New Zealand (or Auckland) correspondent. My only correspondence with the society during the 34 years 1 have been in this colony was to answer an application from the secretary, who asked me whether I would allow extracts from a paper on Compulsory Vaccination which I had read here before our branch of the $\mathrm{N} \mathrm{Z}$. Institute to be published by the society. My reply was that they might reprint the whole paper (which was not a long one) if they liked, but that I would not allow extracts to be made. I have never had a reply to this. My object in refusing to allow extracts was that I knew they would pick out certain cases of vaccinosyphilis which $I$ had seen in the diys of arm to-arm vaccinafion, and not reprint the statement I made that no one who had seen a bad case of confluent small-pox would hesitate about preferring the risks attendant on vaccination to the risks of incurring such a disease as small-pox. But as small-pox has never been epidemic here I see no necessity for enforcing vaccination.
I may mention that as physician of the small-pox hospital in Port of Spain. Trinidad, during the epidemic of 1871-72, I saw two cases of contluent small-pox both of whom had had conflaent small-pox before in the severe epidemic. One I had had under my own care, the other one was seen in the hospital by the medical man who had attended him in the first attack. These ca ses are given in my little work on "The Pathology and Treatment of Small-pox," published in 1872. I have had to bear a good deal of odium on account of my opposition to compulsory vaccination, and some people have treated me as a heretic about vaccination. I am perfectly orthodox on the subject and always have been.

I am, Sir, yours faithfully,

R. H. BAKEWELL, M.D. St. And. Surgeon-Captain (retired) Army Medical Staff. Auckland, N.Z., Nov. 10th, 1907.

\section{THE POWER OF LOCAL AUTHORITIES TO PROVIDE HOSPITALS.}

\section{To the Editor of THE LANCET.}

SIR - The answers to the questions put by " J. S." in TH. LANCET, of Dec. 21st, 1907, p. 1793, seem to me to be as follows:-

1. The education authorities have power compulsorily to acquire sites for their hospitals, because the provision of these hospital and vac ation school sites, \&o., is by Saction 13 of the Edacation (Administration Provisions) Act, 1907, included in the powers and duties of a local education art 'ority under Part III. of the Education Act, 1902. For the parposes of Part III. of the Act of 1902 land may be taken in one of three ways : $(a)$ by agreement under the agreement sections of the Lands Clauses Oonsolidation Acts, which Acts are expressly incorporated in the Elementary Education Act, 1870 , c. 75 , s. 20 (1) (unrepealed) ; (b) under the Sohool Sites Acts (Elementary Education Act, 1870, c. 75, s. 20, last clauses unrepealed); (o) "Otherwise than by agreement," that is, compulsorily under the Land Clauses Consolidation Acts.

2. With regarl to the question of employing qualified medical practitioners I think that the eductition authority can employ any suitable person, whether a qualified medical practitioner or not. There is no provision in the Act. Section 136 of the Public Health Act, 1875, gives the local autbority power in cases of any formidable epidemic disease to "appoint and pav such medical or other officers or persons and do and prozide all such matters and things as may be n ecessary for mitigating such disease, or for superintending or aiding in the execution of such regulations." Although that section only applies in case of a formidable epidemic, yet we may draw the inference that as the local education authority has authority to establish hospitals it has the power to appoint any qualified nurses, or, in fact, any suitable person to look after them. In the case of a smallpox hospital the Local Government Board has not objected to the medical officer of health acting as medical superintendent, but it considers, in view of the duties which he has to perform as medical officer of health, that it would be undesirable that he should reside in the hospital.

3. I think that the treatment need not be free, for the education authority has power under the Elementary Education Act, 1870 , c. 75 , s. 3 (still unrepealed), to charge pupils fcr education in their elementary schools any sum not exceeding ninepence per week per scholar, consequently the anthority would seem to have the power of charging for medical attendances when the parents are capable of paying.

4 The authority does not appear to have the power to admit to such hospitals the cuildren of ratepayers who do not send their children to the elementary schools, for Section 13 specially mentions children attending elementary schools.

5. I think that the local education authority may, with the approval of the Board of Education, supply free of charge spectacles and surgical appliances under s 13 , subs. $1(b)$ of the Act of 1907. I think that the words, "the power to make such arrangements as may be sanctioned by the Board of Education for attending to the health and physical condition," confer such power.

6. I am of opinion that the authority can decide that the child requires spectacles and that the parent can afford to pay for them, and if the child comes to school without spectacles the authority can refuse it admission and prosecute the parent for not sending it to school, as such a rule would 